\title{
STIMULASI PERKEMBANGAN MOTORIK KASAR DI MASA PANDEMI COVID-19 USIA 5-6 TAHUN
}

\author{
Ika Dewi Sartika \\ Program Studi Pendidikan Islam Anak Usia Dini \\ Fakultas Tarbiyah dan Keguruan, UIN Alauddin Makassar \\ E-mail: ikadewisartika6@gmail.com \\ Umi Kusyairy \\ Program Studi Pendidikan Islam Anak Usia Dini \\ Fakultas Tarbiyah dan Keguruan, UIN Alauddin Makassar \\ E-mail: umi.kusyairi@uin-alauddin.ac.id \\ Muh. Rapi \\ Program Studi Pendidikan Islam Anak Usia Dini \\ Fakultas Tarbiyah dan Keguruan, UIN Alauddin Makassar \\ E-mail: mrapi@uin.alauddin.ac.id
}

\begin{abstract}
Abstrak
Tujuan dari penelitian ini: (1) untuk mengetahui bentuk stimulasi perkembangan motorik kasar pada anak usia 5-6 tahun selama pandemi covid19; dan (2) untuk mengetahui faktor pendukung dan penghambat dalam memberikan stimulasi perkembangan motorik kasar pada anak usia 5-6 tahun selama pandemi covid-19. Metode yang digunakan yaitu metode kualitatif deskriptif. Teknik pengumpulan data yang digunakan yaitu observasi dan wawancara. Hasil penelitian ini menunjukkan bahwa (1) bentuk stimulasi untuk perkembangan motorik kasar pada anak usia 5-6 tahun sangat beragam seperti memberikan kebebasan anak untuk bermain sepeda, senam, bulutangkis, berjalan diatas papan titian, berlari, bermain bola sedangkan untuk kegiatan dalam rumah membantu orangtua seperti menyapu serta mencuci piring. Kegiatan tersebut tidak terlepas dari pantauan orangtua terlebih untuk kebersihan dan kesehatan anak sehingga kegiatan mencuci tangan dan membuang sampah pada tempatnya. (2) Faktor pendukung sebagai berikut: lingkungan masyarakat yang kondusif, bimbingan dari sekolah, pemberian motivasi, kebutuhan gizi dan kreativitas orangtua selama pandemi covid-19. (3) Faktor penghambat seperti kecanduan gadget yang memicu kemalasan anak, minimnya peran ayah dalam pengasuhan, serta kurangnya penerapan protokol kesehatan.
\end{abstract}

Kata Kunci: Anak Usia 5-6 Tahun; Pandemi Covid-19; Stimulasi Motorik Kasar

\section{Abstract}

The purpose of this study: (1) to define the forms of gross motor development stimulation in children aged 5-6 years during the covid-19 pandemic; and (2) to identify contributing factors and inhibitors in providing gross motor 
development of the children. The method used was a descriptive qualitative method. The data-collection technique used was observation and interview. The findings suggest that (1) giving children the freedom to play bicycles, gymnastics, flying, walking on footboards, running, playing soccer, and engaging in in-home tasks such as sweeping and washing dishes can help them improve gross motor skills. All activities were under parents' supervision to keep the children clean and healthy, such as asking them to wash their hands and put garbage in its proper place. (2) contributing factors were supportive community environment, school guidance, motivational giving, nutritional needs, and parental creativity during the covid-19 pandemic. (3) inhibitor factors such as gadgets addiction trigger a child's laziness, a lack of parenting, and a lack of application of health protocols.

Keywords: Children Aged 5-6 Years; Covid-19 Pandemic, Gross Motor Stimulation

\section{PENDAHULUAN}

Anak usia dini berada pada masa keemasan atau golden age. Dikatakan sebagai masa keemasan karena sangat berharga dibanding usia-usia selanjutnya. Pada masa ini hampir seluruh potensi anak mengalami masa peka untuk tumbuh dan berkembang secara cepat dan hebat. Sebab di setiap fase perkembangannya, anak tidak hanya tumbuh dari segi fisik semata, melainkan juga dari segi psikologis hingga intelegensinya (Susanto, 2014). Usia dini memiliki peranan penting dalam menentukan pertumbuhan dan perkembangan anak selanjutnya, sebagai pondasi dasar bagi pembentukan kepribadian anak. Anak yang mendapatkan pembinaan sejak dini akan dapat meningkatkan kesehatan dan kesejahteraan fisik, serta mentalnya (Susanto, 2017). Pada dasarnya setiap anak memiliki pertumbuhan dan perkembangan yang berbeda-beda dan pada usia the golden age ini, tumbuh kembang anak dalam segala aspek sangat pesat harus dicapai semaksimal mungkin. Perkembangan anak usia dini mencakup berbagai aspek. Aspek-aspek yang menstimulasi tumbuh kembang anak yaitu aspek perkembangan fisik motorik, aspek perkembangan kognitif, aspek perkembangan bahasa, aspek perkembangan sosial-emosional, aspek perkembangan moral dan agama dan aspek perkembangan seni. Salah satu potensi anak usia dini yang perlu diperhatikan dan dikembangkan yaitu perkembangan fisik-motorik anak khususnya motorik kasar anak. Kondisi fisik motorik memang sangat menjadi perhatian sebab tumbuh kembang anak akan mempengaruhi kehidupan mereka dimasa mendatang. Sehingga mengetahui perkembangan motorik anak, memaksimalkan perkembangan motorik anak serta pentingnya pengembangan motorik anak menjadi suatu keharusan untuk pahami.

Perkembangan motorik kasar (groos motor skill) meliputi keterampilan otototot lengan, kaki, dan batang tubuh, seperti melompat, berjalan, dan berlari (Desmita, 2016). Dalam mengembangkan motorik kasar bagi anak usia dini memiliki beberapa manfaat terutama dalam melatih gerakan, mengontrol gerakan tubuh dan 
koordinasi, kemampuan mengelolah, meningkatkan keterampilan tubuh dan cara hidup sehat. Kemampuan motorik anak pada usia 5-6 tahun yaitu, melakukan gerakan tubuh secara terkoordinasi untuk melatih kelenturan, keseimbangan dan kelincahan, melakukan koordinasi gerakan kaki-tangan-kepala dalam menirukan tari atau senam, melakukan permainan fisik dengan aturan, terampil menggunakan tangan kanan dan kiri, dan melakukan kegiatan kebersihan (Latif, Zukhairina, Zubaidah, \& Afandi, 2016).

Setiap anak mengalami perkembangan motorik kasar yang berbeda-beda. Ada yang berkembang secara lambat adapula yang cepat tergantung stimulasi yang diberikan oleh orangtua. Berdasarkan hasil pengamatan awal yang peneliti lakukan pada tanggal 3 Februari 2021 - 5 Februari 2021 di Perumahan Zarindah Permai terdapat beberapa anak yang masih kaku bergerak saat bermain bersama. Terlihat saat bermain di lorong perumahan, ada anak yang mampu berlari cepat dan ada juga yang agak lambat, ada yang harus menggunakan sepeda roda tiga agar dapat mengayuh dengan leluasa dan ada yang mudah sekali mengayuh sepeda roda dua. Hal ini terlihat pula saat dilakukan senam bersama teman sebaya beserta peneliti dan teman-temannya saat sore hari terdapat anak yang terlihat susah untuk mengkolaborasikan gerakan senam. Oleh karena itu penting bagi orangtua untuk memberikan stimulasi yang tepat kepada anak sehingga perkembangan motorik anak dapat berkembang secara optimal. Terlebih kondisi sekarang mengharuskan kegiatan belajar mengajar dilakukan secara daring karena adanya pandemi covid-19 sehingga menjadi tantangan bagi orangtua.

Munculnya pandemi covid-19 dianggap oleh beberapa orangtua menghambat kegiatan belajar mengajar yang biasanya berlangsung secara tatap muka. Hal ini sejalan dengan hasil penelitian yang dilakukan oleh Winarti, Taib, Alhadad, \& Achmad (2021) bahwa adanya virus covid-19 ini menunjukkan semakin pentingnya peran orang tua dalam membimbing anak belajar dirumah menggantikan tugas guru disekolah. Namun hal ini menjadi kejutan besar bagi para orang tua, terlebih yang tidak biasa mendampingi anak belajar di rumah yang tentu saja menimbulkan berbagai masalah atau kendala baru yang dialami oleh orang tua, seperti kurangnya pemahaman materi oleh orang tua, kesulitan orang tua dalam menumbuhkan minat belajar anak, tidak memiliki cukup waktu untuk mendampingi anak karena harus bekerja, orang tua tidak sabar dalam mendampingi anak saat belajar dirumah, oleh karena itu perubahan membutuhkan waktu untuk bisa berjalan optimal.

Peran orangtua sangat dibutuhkan untuk memberikan edukasi kepada anak terutama anak usia 5-6 tahun yang cenderung belum memahami kondisi sekarang. Peran orangtua yang muncul secara umum selama pandemi ini yakni sebagai pembimbing, pendidik, penjaga, pengembang dan pengasawan selain itu untuk menjaga dan memastikan anak untuk menerapkan hidup bersih dan sehat, mendampingi anak pada saat mengerjakan tugas sekolah, melakukan kegiatan bersama selama dirumah, bermain bersama anak, memotivasi dan membimbing 
anak serta memberikan edukasi khusunya mengenai perkembangan motorik kasar pada anak. Berangkat dari permasalahan tersebut, maka peneliti akan mengkaji Stimulasi Perkembangan Motorik Kasar Pada Anak Usia 5-6 Tahun Selama Pandemi Covid-19. Tujuan dari penelitian ini: (1) untuk mengetahui bentuk stimulasi perkembangan motorik kasar pada anak usia 5-6 tahun selama pandemi covid-19; (2) untuk mengetahui faktor pendukung dalam memberikan stimulasi perkembangan motorik kasar pada anak usia 5-6 tahun selama pandemi covid-19; (3) untuk mengetahui faktor penghambat dalam memberikan stimulasi perkembangan motorik kasar pada anak usia 5-6 tahun selama pandemi covid-19.

\section{METODE PENELITIAN}

Jenis penelitian yang digunakan adalah penelitian kualitatif deskriptif. Penelitian ini dilakukan dengan mengumpulkan data-data berisi informasi mengenai bentuk stimulasi perkembangan motorik kasar pada anak usia dini. Lokasi penelitian bertempat di Jl. Veteran Bakung Perumahan Zarindah Permai, Kelurahan Samata, Kecamatan Sumba Opu, Kabupaten Gowa. Pada penelitian ini, peneliti menggunakan pendekatan yakni: pendekatan pedagogik dan pendekatan psikologis. Sumber data yang digunakan adalah sumber data primer yaitu para orangtua anak (SM, SHY, dan INY) dan sumber data sekunder diperoleh dari hasil observasi pada anak yang berusia 5-6 tahun (RNR, DGS dan HA). Teknik pengumpulan data yang digunakan yaitu observasi dan wawancara. Teknik analisis data yang digunakan yaitu reduksi data, penyajian data, serta penarikan kesimpulan dan verifikasi.

\section{HASIL DAN PEMBAHASAN}

Berdasarkan hasil wawancara dari orangtua anak, peneliti mampu menyimpulkan bahwa stimulasi-stimulasi untuk melatih perkembangan motorik kasar pada anak usia 5-6 tahun sangat beragam. Pertama, stimulasi untuk melatih kelenturan anak itu berupa permainan permainan outdoor seperti bermain bola, berjalan dipapan titian, bermain bulutangkis, peta umpet, bermain sepeda. Untuk dalam ruangan seperti naik turun tangga, membantu orangtua menyapu dan cuci piring, membuang sampah, dan meniru gerakan yang ada pada handphone seperti gerakan tiktok. Kedua, stimulasi untuk melatih keseimbangan anak para orangtua subjek sekunder membebaskan anaknya untuk bermain seperti bermain sepatu roda, bermain sepeda dan berjalan diatas papan titian. Seperti yang dikatakan oleh orangtua DGS untuk keseimbangan anak selama pandemi covid-19 ini ibu dari DGS memberikan kebebasan bermain sepeda saat sore hari di depan rumah. Ketiga, hasil wawancara bersama para orangtua subjek penelitian tekait bentuk stimulasi untuk melatih kelincahan anak seperti melakukan permainan bulutangkis, bermain sepeda, bermain tembak-tembakkan di dalam rumah, dan bermain bola.

Hasil observasi yang dilakukan pada subjek penelitian terkait melakukan gerakan tubuh secara terkoordinasi untuk melatih kelenturan, kelincahan, 
keseimbangan dan kelincahan. Terdapat tiga aspek yang diamati diantaranya anak mampu meremas kertas hingga berbentuk bola, anak mampu berjalan dipapan titian tanpa bantuan, dan anak mampu berjalan dengan satu kaki diatas papan titian. Berdasarkan hasil observasi untuk aspek yang pertama RNR dan HA berkembang sangat baik saat meremas kertas hingga berbentuk bola sedangkan DGS berkembang sesuai harapan saat meremas kertas hingga berbentuk bola. Sedangkan untuk aspek yang kedua DGS berkembang sangat baik saat berjalan diatas papan titian tanpa bantuan, sedangkan RNR dan HA berkembang sesuai harapa saat berjalam diatas papan titian tanpa bantuan. Untuk aspek ketiga, RNR berkembang sesuai harapan saat berjalan diatas papan titian dengan menggunakan satu kaki sedangkan DGS dan HA mulai berkembang saat berjalan dengan satu kaki diatas papan titian.

Kemampuan anak untuk dapat melakukan gerakan tubuh secara terkoordinasi dibutuhkan untuk melatih kelenturan, keseimbangan, dan kelincahan. Dari hasil wawancara bersama para orangtua subjek cara yang dilakukan untuk melatih kelenturan, keseimbangan, dan kelincahan anak dilakukan dengan pemberian permainan-permainan outdoor maupun indoor seperti bermain bola, badminton, bermain sepeda, berjalan diatas papan titian, membantu kegiatan orangtua seperti mencuci piring dan membuang sampah.Kelenturan adalah batas rentang gerak maksimal yang mungkin pada sebuah sendi atau rangkaian sendi dapat dikembangkan melalui latihan-latihan peregangan otot. Kelenturan adalah batas rentang gerak maksimal yang mungkin pada sebuah sendi atau rangkaian sendi dapat dikembangkan melalui latihan-latihan peregangan otot. Kelenturan dapat diransang melalui kegiatan-kegiatan ataupun permainan. Kegiatan yang dirancang untuk mengembangkan kelenturan gerak tubuh anak merupakan demonstrasi gerak, menirukan gerakan-gerakan luwes yang dilihat atau dipersepsikan, dan menciptakan gerak (Moqowin, 2018). Seseorang dikatakan lentur apabila ia mampu menggerakkan tubuhnya tanpa ada rasa kaku sedikitpun. Keseimbangan merupakan kemampuan seseorang untuk mempertahankan kesetimbangan tubuh ketika ditempatkan pada berbagai posisi sebagai anak yang sedang tumbuh, anak yang berusia 5-6 tahun menjadi lebih terampil dalam bergerak (Pratiwi \& Munawar, 2014). Selanjutnya untuk kelincahan merupakan kemampuan seseorang dalam mengubah posisi secepat mungkin sesuai dengan situasi yang dihadapi dan dikehendaki.

Kegiatan-kegiatan tersebut melatih otot kaki dan tulang punggung anak sehingga dapat melakukan gerakan tubuh secara terkoordinasi untuk melatih kelenturan, keseimbangan, dan kelincahan. Hal ini sesuai dengan ungkapan Sudono (Ivo Yani) bahwa ciri-ciri anak usia 5-6 tahun diantaranya (a) gerakan yang lebih tangkas, (b) berjalan dan melangkah lebih tegap, (c) dapat mengatur keseimbangan tubuh, (d) berdiri dengan satu kaki lebih dari 8 detik, (e) bermain kelompok dengan sampai lima orang teman, serta (e) bekerjanya terpacu oleh kompetisi (Yani, 2017). 
Keempat, untuk melatih koordinasi gerakan mata-kaki-tangan-kepala dilakukan dengan pemberian stimulasi seperti senam atau tarian, dua diantara tiga anak tersebut piawai dalam menirukan gerakan senam ataupun tarian dan terdapat seseorang anak yang terlihat kaku. Para orangtua subjek mengatakan bahwa mereka mampu menyelaraskan gerakan mata-kaki-tangan-kepalanya saat melakukan senam ataupun tarian.

Pemberian stimulus ini sangat jarang diberikan oleh orangtua, namun anak lebih banyak belajar melalui saudaranya dan belajar sendiri dari smartphone. Selain itu orangtua $\mathrm{HA}$ pun mengatakan bahwa pemberian stimulasi senam itu tidak pernah diberikan namun saudara dari HA yang selalu mengajak dan mengajarkan HA untuk melakukan kegiatan senam. Adapun hasil observasi terkait koordinasi gerakan matakaki-tangan-kepala dalam menirukun tarian atau senam terdapat dua aspek yang diamati yaitu anak mampu menggerakkan tubuhnya pada saat senam dan anak mampu menggerakkan tubuhnya pada saat melakukan gerakan tarian. Berdasarkan hasil observasi dari aspek yang pertama DGS dan RNR berkembang sesuai harapan saat melakukan gerakan senam sedangkan HA belum berkembang saat melakukan gerakan senam terlihat masih kaku. Untuk aspek yang kedua DGS dan RNR berkembang sesuai harapan saat melakukan gerakan taria-tarian sedangkan HA mulai berkembang saat melakukan gerakan tarian.

Pembelajaran keterampilan gerak melalui kegiatan senam/tari merupakan upaya untuk melatih kemampuan fisik anak melalui kegiatan yang membuat anak nyaman, ekspresif dan kreatif dan juga dapat menyalurkan perasaan senang dan bahagia. Sumandiyo Hadi mengatakan bahwa menari diberikan utnuk mempresentasikan banyak perasaan seperti rasa senang, kebebasan, gairah, bahagia, kekuatan dan keagungan (Diana, R, \& Astuti, 2014). Melalui kegiatan senam dan menari anak akan bergerak mengikuti gerakan yang ada dalam kegiatan tersebut dengan gembira sehingga anak semakin terampil dalam bergerak. Hal ini dikarenakan anak usia dini pada dasarnya merupakan makhluk yang senang bergerak. Dalam kegiatan senam dan menari banyak kemampuan yang diperoleh anak seperti cara berfikir anak untuk bisa menghafal gerakan dan mampu mendengar musik serta menyesuaikan dengan gerakannya.

Kelima, melakukan permainan fisik dengan aturan. Terkait permainan fisik sesuai dengan aturan. Terdapat dua aspek yang diamati diantaranya anak mampu memainkan perannya saat bermain peran dan anak mampu bermain bola sesuai dengan aturan. Dari hasil observasi untuk aspek yang pertama DGS berkembang sangat baik saat melakukan permainan bermain peran dilihat saat bermain masakmasak DGS menjadi koki yang handal dalam memasak sedangkan RNR dan HA berkembang sesuai harapan saat melakukan permainan bermain peran dapat dilihat saat RNR jadi perawat dan merawat pasien dan HA saat menjadi tukang kebun yang menyiram tanamannya. Aspek yang kedua ketiga subjek berkembang sesuai harapan saat bermain bola dan sesuai dengan aturan. Dilihat saat bermain ketiga 
subjek penelitian tidak saling rebutan bola saat bermain dengan lawan mainnya.

Berdasarkan hasil wawancara dari para orantua mengenai permainan fisik yang diberikan selama dirumah, yang sering diberikan seperti bermain bola, bermain oper-oper bola, bermain peran, dan bermain bulutangkis. Permain ini dilakukan sesua dengan aturan yang diterapkan oleh masing-masing orangtua anak seperti pada saat selesai berimain anak wajib merapikan mainannya sendiri.

Perkembangan fisik anak berbeda satu sama lain, sekalipun anak-anak tersebut usianya relatif sama dan kondisi ekonomi yang sama pula. Anak harus diberikan berbagai macam kegiatan fisik yang beragam untuk melatih kemampuan bergeraknya, Elizabeth B. Hurlock mengatakan proses motorik merupakan gerakan yang langsung melibatkan otot untuk bergerak dan proses persyaratan yang menjadikan seseorang mampu menggerakkan anggota tubuhnya (Khadijah \& Amelia, 2020). Jika anak melakukan aktivitas fisik atau gerakan dengan baik maka untuk aktivitas selanjutnya anak akan menjadi percaya diri dalam melakukan suatu kegiatan atau anak ikut serta dalam kegiatan pengembangan fisik tersebut.

Keenam, dalam melakukan berbagai kegiatan bermain anak sangat aktif dan terampil dalam menggunakan kedua tangannya walaupun terdapat anak yang lebih dominan menggunakan tangan kiri namun orangtua selalu mengajarkan anak untuk mengunakan tangan kanannya juga agar tercipta keseimbangan. Hal ini didukung dari hasil observasi terkait keterampilan menggunakan tangan kanan dan kiri. Adapun aspek yang diamati yaitu anak mampu melempar bola. Berdasarkan hasil observasi RNR dan HA berkembang sangat baik saat melempar bola kedua subjek tersebut sangat piawai dalam bermain bola baik itu menangkap maupun melempar bola sedangkan DGS berkembang sesuai harapan saat bermain lempar bola. Ketiga subjek terampil dalam menggunakan kedua tangannya.

Ketujuh, Para orangtua mengatakan bahwa penting melakukan kegiatan kebersihan diri karena sekarang wabah covid-19 terus berlanjut anak dibiasakan untuk selalu mencuci tangan dengan air mengalir dan memakai sabun dan terbukti ketiga anak tersebut sangat pandai mencuci tangannya sendiri, begitupun dengan sampah, anak terbiasa membuang sampahnya sendiri ketempat sampah. Selain dari pembiasaan orangtua pun selalu mengingatkan kepada anak agar selalu menjaga kebersihan diri dan lingkungan. Selaras dengan hasil observasi yang dilakukan pada subjek penelitian terkait kegiatan kebersihan diri. Terdapat tiga aspek yang diamati diantaranya anak mampu membuang sampah pada tempatnya, anak mampu merapikan mainannya sendiri sehabis bermain, dan anak mampu mencuci tangan sebelum dan sesudah berkegiatan.

Berdasarkan hasil observasi untuk aspek yang pertama DGS berkembang sangat baik saat melakukan kebersihan membuang sampah pada tempatnya tanpa harus diingatkan lagi sedangkan RNR dan HA berkembang sesuai harapan saat melakukan kegiatan kebersihan membuang sampah pada tempatnya. Kedua subjek penelitian harus sering diingatkan untuk hal tersebut. Aspek kedua DGS dan RNR 
sudah berkembang sangat baik dalam merapikan mainannya sendiri sehabis bermain tanpa perlu bantuan orangtuanya lagi ataupun kakaknya. Sedangkan HA masih berkembang sesuai harapan saat merapikan mainannya sendiri sehabis bermain walaupun masing sering diingatkan dan dibantu oleh kakaknya. Untuk aspek ketiga yaitu anak mampu mencuci tangan baik sebelum maupun sesudah berkegiatan ketiga subjek penelitian tersebut sudah berkembang sangat baik dalam hal tersebut karena saat penting untuk menjaga kesehatan tubuh agar terindar dari covid-19. Para orangtua tersebut selalu mengingatkan anak dan mengajarkan anak untuk selalu mencuci tangan dengan sabun.

Keluarga merupakan pokok utama dalam perilaku hidup bersih dan pencegahan kesehatan secara dini. Meluasnya wabah covid-19 mengharuskan kita untuk mengikuti 3M dari Pemerintah. 3M merupakan kunci utama penanganan covid-19 diantaranya memakai masker, menjaga jarak dan mencuci tangan pakai sabun. Dalam wawancara bersama orangtua subjek salah satu cara mereka yang sering dilakukan untuk menghindakan anak dari covid-19 yaitu mencuci tangan. Menurut WHO (Enie Novieastari, dkk) perilaku mencuci tangan hendaknya diterapkan di 10 tahun pertama kehidupan seseorang (Novieastari, Kusman Ibrahim, \& Ramdaniati, 2020). Perilaku ini memberikan pengaruh terhadap perilaku seseorang terhadap kebersihan tangan sepanjang masa. Selain mencuci tangan, perilaku seperti membuang sampah juga penting karena termasuk perilaku hidup bersih. Untuk membiasakan etika ini orangtua perlu menghilangkan kebiasaan membang sampah tidak pada tempatnya karena anak peniru ulung. Memang anak adalah peniru ulung bahkan masa balita disebut juga masa imitasi dan identifikasi.

Masa imitasi mengacu pada meniru apapun yang dilakukan oleh orang-orang disekitarnya terutama keluarga karena anak banyak menghabiskan waktu dengan keluarga. juga dikenal sebagai masa identifikasi karena selain meniru anak juga mengadopsi cara berfikir orangtuanya. Hingga tanpa disadari karakter anak terbentuk sesuai dengan lingkungannya (Farid, 2019). Oleh karena itu masa golden age ini merupakan masa penting dalam pembentukan karakter pada anak, melalui contoh dari kedua orangtua salah satunya melakukan kegiatan kebersihan mencuci tangan dengan sabun dan membuang sampah pada tempatnya.

Peran orangtua sangatlah penting dalam pemberian stimulasi tersebut Karena sangat penting dan paling utama untuk melatih perkembangan motrik kasar pada anak. Selain dari lingkungan keluarga lingkungan masyarakat pun. Hasil wawancara terkait kendala yang orangtua alami selama pemberian stimulasi perkembangan motorik kasar pada anak selama pandemi covid-19 peneliti mampu menyimpulkan ada beberapa kendala yang orangtua anak alami dalam pemberian stimulus tersebut kepada anaknya seperti: anak keseringan menggunakan hanphone sehingga anak bermalas-malasan dalam melakukan kegiatan, anak juga kadang jadi pelupa dan harus terus diingatkan, terkadang juga orangtua kurang mengerti dengan pelajaran anak sehingga belajarnya diarahkan kesaudaranya, dan sekarang anak lebih banyak 
belajar dari rumah jadi pemberian stimulasi untuk melatih perkembangan fisik dari sekolah mulai sangat kurang. Karena kebanyakan anak melakukan kegiatan perkerjaan rumah seperti menulis dan belajar menghitung. Selain dari kendala orangtua faktor pendukung pun menjadi peran penting untuk menstimulasi perkembangan motorik kasar anak.

Hasil wawancara dari orangtua anak peneliti dapat minyimpulkan beberapa faktor yang dapat menunjang perkembangan motorik kasar anak diantaranya; lingkungan masyarakat yang kondusif, bimbingan dari sekolah, pemberian motivasi, kebutuhan gizi, serta lingkungan keluarga. Termasuk peran ayah sangat berpengaruh untuk perkembangan motorik anak agar tidak terdapat ketimpangan peran antara ayah dan ibu sehingga stimulusnya khusus motorik kasar terpenuhi sepenuhnya karena kedekatan ayah dengan anak sangat dibutuhkan juga.

Banyak orang yang beranggapan bahwa pengasuhan anak merupakan tugas ibu tetapi menurut peneliti peran ayah juga dibutuhkan. Ayah termasuk patner dalam pengasuhan anak artinya ayah memiliki hak dan tanggung jawab yang sama dengan ibu peran ayah dalam pengasuhan anak adalah keikutsertaan ayah dalam mengasuh atau menstimulasi pertumbuhan dan perkembangan anak baik fisik, mental dan sosial. Hal tersebut menjadi bukti bahwa selain keakrapan anak tidak serta merta keibunya terus keakrapan ayah dan anakpun harus dibangun serta peran ayah pun sangat dibutuhkan. Sejalan dengan penelitian yang dilakukan oleh (Novela, 2019) menyimpulkan bahwa sosok seorang ayah sangat mempengaruhi pertumbuhan dan perkembangan anak melalui berinteraksi dengan ayahnya sehingga anak mendapat pengalaman yang akan ia contoh. Kedekatan antara seorang ayah dan anak membuat sebuah keharmonisan didalam keluarga sosok ayah dan sosok seorang ibu tidak dapat digantikan oleh siapapun, masing-masing mereka sudah memiliki peran.

Berdasarkan hasil wawancara dan observasi dilapangan dapat disimpulkan bahwa bentuk stimulasi untuk perkembangan motorik kasar pada anak berusia 5-6 tahun sangat beragam seperti memberikan kebebasan anak untuk bermain sepeda, senam, bulutangkis, berjalan diatas papan titian, berlari, bermain bola sedangkan untuk kegiatan dalam rumah membantu orangtua seperti menyapu serta mencuci piring. Melihat kondisi sekarang kegiatan tersebut tidak terlepas dari pantauan orangtua terlebih untuk kebersihan dan kesehatan anak sehingga kegiatan mencuci tangan dan membuang sampah pada tempatnya menjadi hal pokok untuk diajarkan. Selain itu ada beberapa faktor yang mempengaruhi perkembangan motorik kasar pada anak usia 5-6 tahun diantaranya faktor pendukung da penghambat. Faktor pendukung seperti lingkungan yang kondusif, bimbingan dari sekolah, pemberian motivasi, seta kebutuhan gizi. Untuk faktor penghambat seperti penggunaan gadget dan pola asuh orangtua.

Keterbatasan penelitian ini adalah kurangnya pengetahuan dan pengalaman peneliti dalam melakukan penelitian. Peneliti sudah berusaha semampu mungkin 
untuk melakukan penelitian sesuai dengan kemampuan keilmuan serta arahan dan bimbingan dari dosen pembimbing agar mendapatkan hasil yang sesuai, hasil penelitian bersifat subjektif, dan peneliti bertanggung jawab penuh terhadap segala informasi yang disampaikan oleh para sumber penelitian. Penelitian ini memiliki sejumlah kesamaan dengan penelitian deskripitf kualitatif sebelumnya, namun yang menjadi pembeda adalah penelitian yang sedang dikaji oleh peneliti mengupayakan agar anak tetap memperoleh stimulasi dalam perkembangan motorik kasarnya meskipun dilakukan pada masa pandemi covid-19. Sehingga kegiatan pemberian stimulasi dapat berjalan lebih maksimal karena setiap anak masing-masing mendapat stimulasi penuh oleh guru dengan bantuan orangtua. Selain itu stimulasi tersebut tidak hanya dapat dilakukan di sekolah atau diwaktu tertentu, tetapi dapat dilakukan kapan saja dan dimana saja.

\section{KESIMPULAN}

Setelah dilakukan analisis dan pembahasan secara mendalam terhadap data hasil penelitian di lapangan, penelitian ini menghasilkan temuan dan kesimpulan sebagai berikut: (1) Bentuk stimulasi untuk perkembangan motorik kasar pada anak usia 5-6 tahun sangat beragam. Untuk menstimulasi kelenturan, keseimbangan dan kelincahan anak beberapa kegiatan dan permainan diberikan untuk melatih perkembangan motorik kasar anak tersebut kegiatan diluar ruangan bermain bola, bermain bulutangkis dan bermain sepada. Untuk melatih koordinasi gerakan matakaki-tangan-kepala dilakukan dengan pemberian stimulasi seperti senam atau tarian, selain itu beragam permainan fisik juga yang diberikan seperti bermain peran, bermain bulutangkis dansepatu roda. Kegiatan-kegiatan tersebut dilakukan menggunakan kedua tangannya sehingga anak mahir dalam menggunakan kedua tangan. Selanjutnya kebersihan diri juga penting untuk diterapkan kepada anak seperti mencuci tangan dan memakai sabun serta membuang sampah pada tempatnya karena sekarang wabah virus semakin meningkat. (2) Faktor pendukung dalam memberikan stimulasi perkembangan motorik kasar pada anak usia 5-6 tahun selama pandemi covid-19 sebagai berikut: a) Lingkungan masyarakat yang kondusif; b) Bimbingan dari sekolah; c) Pemberian motivasi; d) Kebutuhan gizi; serta e) Kreativitas orangtua selama pandemi covid-19 dan (3) Faktor penghambat yang orangtua anak alami dalam pemberian stimulus tersebut kepada anaknya seperti kecanduan gadget yang memicu kemalasan anak, minimnya peran ayah dalam pengasuhan, serta kurangnya penerapan protokol kesehatan.

\section{DAFTAR PUSTAKA}


Desmita. (2016). Psikologi Perkembangan. Bandung: PT Remaja Rosdakarya.

Diana, K., R, M., \& Astuti, I. (2014). Peningkatan Keterampilan Gerak Melalui Kegiatan Menari Pada Anak Usia 5-6 Tahun. Jurnal Pendidikan Dan Pembelajaran Khatulistiwa., 3(11).

Farid, M. A. (2019). Ungkapan Kasih Ibu Kumpulan Catatan Seputar Parenting. Tasikmalaya: Edu Publisher.

Khadijah, \& Amelia, N. (2020). Perkembangan Fisik Motorik Anak Usia Dini. Jakarta: Kencana.

Latif, M., Zukhairina, Zubaidah, R., \& Afandi, M. (2016). Orientasi Baru Pendidikan Anak Usia Dini Teori Dan Aplikasi. Jakarta: Prenadamedia Group.

Moqowin. (2018). Strategi Pembelajaran Anak Usia Dini Berbasis Multiple Intelligences. Jawa Tengah: Penerbit Mangku Bumi.

Novela, T. (2019). Dampak Pola Asuh Ayah terhadap Perkembangan Anak Usia Dini. Raudhatulathfal:Jurnal Pendidikan Islam Anak Usia Dini, 3(1).

Novieastari, E., Kusman Ibrahim, D., \& Ramdaniati, S. (2020). Dasar-Dasar Keperawatan. Indonesia: Elsevier.

Pratiwi, W. C., \& Munawar, M. (2014). Peningkatan Keseimbangan Tubuh Melalui Berjalan Diatas Versa Disc Pada Anak Kelompok B Paud Taman Belia Candi Semarang. Jurnal Penelitian Paudia, 3(2).

Susanto, A. (2014). Perkembangan Anak Usia Dini: Pengantar dalam Berbagai Aspeknya. Jakarta: Kencana Prenadamedia Group.

Susanto, A. (2017). Pendidikan Anak Usia Dini Konsep dan Teori. Jakarta: Bumi Aksara.

Winarti, S., Taib, B., Alhadad, B., \& Achmad, F. (2021). Analisis Dampak Covid-19 dalam Proses Pembelajaran Daring pada Kelas B4 di PAUD Telkom Ternate. Jurnal IImiah Cahay PAUD, 3(1).

Yani, I. (2017). Stimulasi Perkembangan Anak Melalui Permainan Tradisional Suku Batak Toba. Jurnal IImiah VISI PGTK PAUD Dan DIKMAS, 12(12). 